\title{
A Rare Cause of Ataxia: SPG7 Mutation
} Nadir Bir Ataksi Nedeni: SPG7 Mutasyonu

\author{
(1) Afra Çelik, (1) Banu Özen Barut, (1) Rahşan Adviye İnan \\ University of Health Sciences Turkey, Kartal Dr. Lutfi Kirdar City Hospital, Clinic of Neurology, Istanbul, Turkey
}

\begin{abstract}
Hereditary spastic paraplegias (HSPs) are neurodegenerative disorders characterized by progressive weakness and spasticity in the lower limbs and are clinically and genetically heterogeneous. They are clinically classified as pure and complicated forms. HSP may be inherited as autosomal dominant, autosomal recessive, X-linked, or mitochondrial disorders. A 61-year-old man presented with progressive stiffness, weakness, ataxia in the lower limbs, dysarthria and asymmetric ptosis. None of the family members had such neurological symptoms. Brain magnetic resonance imaging showed cerebellar atrophy. Genetic analysis with whole exome sequencing revealed a homozygous p.Ala572Val (c.1715C $>$ T) exchange mutation in SGP7 gene. SPG 7 mutation is an important cause of adult-onset undiagnosed ataxia. Although the availability of exome sequencing with targeted analysis helps molecular diagnosis of SPG7 easier, it is important to consider SPG7 in the differential diagnosis of adult onset ataxias. In this paper we report a patient with complicated form of HSP with SPG7 mutation.
\end{abstract}

Keywords: Hereditary spastic paraplegia, ataxia, SPG7

\section{Öz}

Herediter spastik paraplejiler (HSP) alt ekstremitelerde ilerleyici güçsüzlük ve spastisite ile karakterize nörodejeneratif natürde klinik ve genetik olarak heterojen bir grup hastalıktır. Klinik olarak pür ve komplike formları bulunmaktadır. Genetik olarak da otozomal dominant, otozomal resesif, X'e bağlı ve mitokondriyal olarak kalıtılabilir. Olgumuz 61 yaşında erkek hasta olup bacaklarda ilerleyici güçsüzlük, sertlik ve dengesizlik, konuşmada bozukluk ve göz kapă̆ında düşme ile başvurdu. Ailesinde benzer bir öykü bulunmayan hastanın beyin manyetik rezonans görüntülemesinde serebellar atrofi izlendi. Tüm ekzom dizileme ile SPG7 geninde homozigot p.Ala572 Val (c.1715C > T) mutasyonu saptandı. SPG7 mutasyonu erişkin başlangıçlı tanı koyulamayan ataksinin önemli sebeplerindendir. Her ne kadar tüm ekzom dizileme gibi yeni nesil dizileme yöntemleri ile moleküler olarak daha kolay tanı koyulabilse de erişkin başlangıçlı ataksilerin ayırıcı tanısında SPG7'yi düşünmek gerekir. Bu yazıda SPG7 mutasyonlu komplike HSP formu tanısı alan bir hastayı sunuyoruz.

Anahtar Kelimeler: Herediter spastik parapleji, ataksi, SPG7

\section{Introduction}

Hereditary spastic paraplegias (HSPs), also known as spastic paraplegias (SPGs) are a group of clinically and genetically heterogeneous neurodegenerative disorders characterized by progressive weakness and spasticity in the lower extremities (1). These key symptoms are due to retrograde degeneration of the longest nerve fibers in the corticospinal tracts and posterior columns (2).

The HSPs are classified clinically as pure and complicated forms. Patients with pure HSP show progressive SPG with hyperreflexia, extensor plantar response, ankle clonus and increased tone in the lower limbs, which can be associated with sphincter disturbances and deep sensory loss. Complicated HSPs consist of SPG and additional neurologic or systemic abnormalities such as cerebellar ataxia, dysarthria, mental retardation, peripheral neuropathy, optic atrophy, deafness, dementia, severe amyotrophy, epileptic seizures, ichthyosis or thin corpus callosum $(1,2,3)$.

To date, over 70 distinct loci and 50 SPG genes have been identified. The mode of inheritance can be autosomal dominant (AD), autosomal recessive (AR), X-linked, or mitochondrial. Also, sporadic HSP is not uncommon (4). The prevalence of HSP is estimated to be 1.8 cases per 100,000 individuals for both ADHSP and ARHSP (5).

Here, we report a case of a Turkish patient with SPG7 mutation, complicated form of HSP and a recessive pattern of inheritance.

\section{Case Reports}

Our patient was a 61-year-old right-handed Caucasian male. At age of forty one, he had noticed gait disturbance and slow and slurry speech. Ten years later, he started using a walking stick and

Address for Correspondence/Yazışma Adresi: Afra Çelik MD, University of Health Sciences Turkey, Kartal Dr. Lutfi Kirdar City Hospital, Clinic of Neurology, Istanbul, Turkey

Phone: +90 5555592098 E-mail: afracelik09@ gmail.com ORCID: orcid.org/0000-0003-1065-0851

Received/Geliş Tarihi: 28.01.2021 Accepted/Kabul Tarihi: 13.08.2021

${ }^{\circ}$ Copyright 2022 by Turkish Neurological Society

Turkish Journal of Neurology published by Galenos Publishing House. 
following the next decade he began needing a walking frame. He also had urine incontinence for the last 5 years. Until his retirement at the age of 51 he was working in their family business focusing on production stainless cast iron. His father died of lung cancer at the age of 67 in 1999 and had no neurological disorders according to our patient. His mother was a 88 -year-old healthy individual. His parents grew up in the same village so they were assumed to be consanguineous. Our patient had one brother (same mother) and two sisters. None of them had similar neurologic symptoms (Figure 1).

His neurological examination revealed cerebellar dysarthria, asymmetric ptosis $(\mathrm{R}>\mathrm{L})$, horizontal gaze-dependent nystagmus. His motor examination was impaired. He had $4 / 5$ muscle strength affecting proximal and $-5 / 5$ muscle strength affecting distal lower extremity muscles. His tonus was increased at legs with brisk patella and Achilles reflexes, and bilateral extensor plantar responses. He had truncal ataxia and his cerebellar tests were impaired including both upper and lower extremities. Dysmetria and dysdiadochokinesia were noted in both upper extremities. Also, the knee-heel test was impaired bilaterally. He had no sensory impairment including vibration and joint position senses. Ophthalmologic examination was normal except asymmetric ptosis. Otolaryngologic examination revealed bilateral mild sensorineural hearing loss. His cognitive examination was done. His mini-mental state examination score was 26/30 and his clock drawing test was normal.

His complete blood count, liver and kidney function tests, electrolyte levels, B12, folate and thyroid hormone levels were normal. His anti-GAD and anti-gliadin antibodies were negative. Nerve conduction studies were normal. Repetitive nerve stimulation performed for asymmetric ptosis was also normal. Electromyography showed only increased motor unit potential amplitudes with longer duration in left L5-S1 root innervated muscles. His lumber magnetic resonance imaging (MRI) showed mild disc bulging at L5-S1 levels. Cranial MRI revealed cerebellar

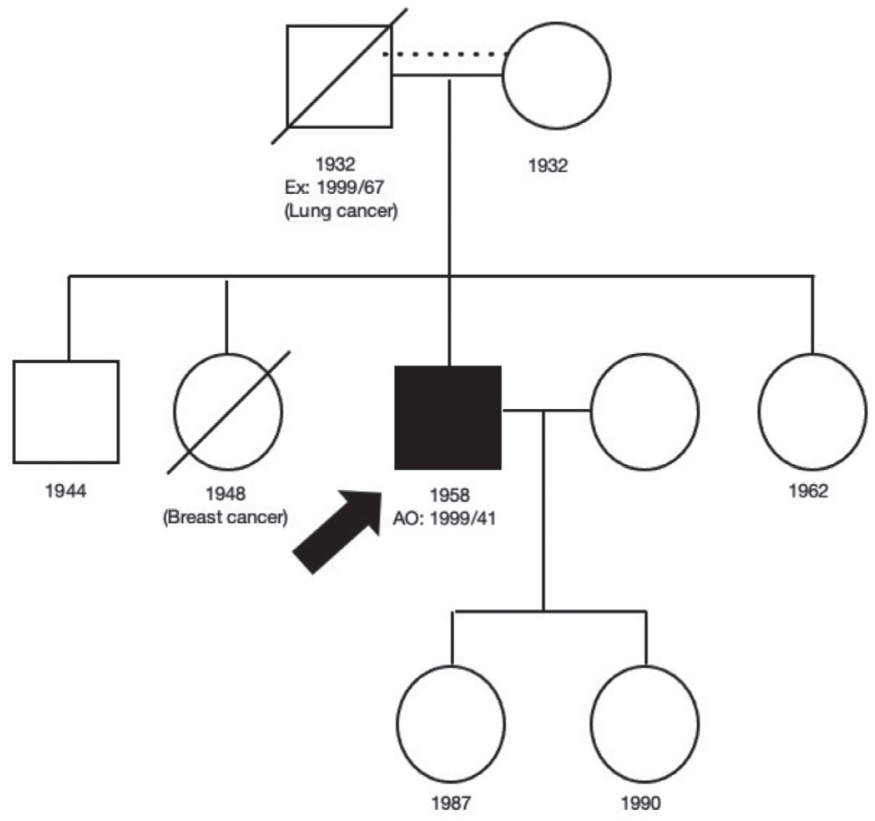

Figure 1. Pedigree atrophy (Figure 2). Cervical and thoracic vertebra MRI for the work-up of spastic paraparesis was not done.
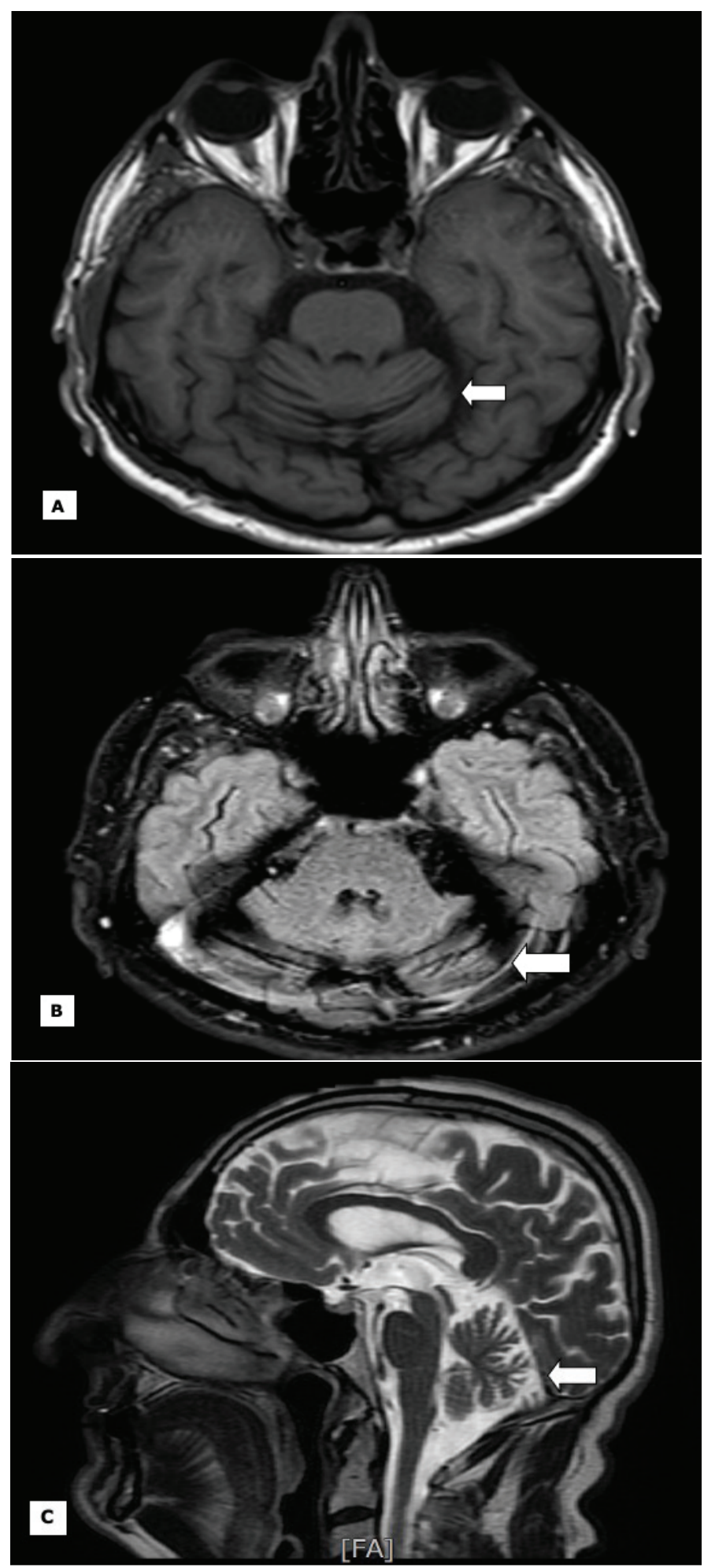

Figure 2. (A) T1 weighted axial image. (B) T2-FLAIR weighted axial image. (C) T2 weighted sagittal image shows cerebellar atrophy (white arrow)

FLAIR: Fluid-attenuated inversion recovery 
He already had been screened for vitamin E levels, anti-GAD antibodies, Friedreich ataxia, SCA1, SCA2, SCA3, SCA6, SCA7, SCA17, during his admissions to different hospitals. The results were negative. We carried out whole exome sequencing analysis of genomic DNA from the patient. A homozygous p.Ala572Val (c.1715C > T) exchange mutation was detected in SPG7 gene.

We diagnosed his disorder as an autosomal-recessive form of hereditary SPG7 based on the characteristic clinical symptoms, MRI findings, and the mutation in SPG7 gene.

\section{Discussion}

SPG7, OMIM\#602783 is one of the most common form of ARHSP caused by mutations in the SPG7 gene. Rare AD transmission has also been described (6). SPG7 gene is located in chromosome 16q24 and encodes paraplegin protein, a subunit of a m-AAA-protease complex located within the inner mitochondrial membrane $(7,8)$. Paraplegin plays a significant role in different cellular activities including membrane trafficking, protein maturation and degradation $(8,9)$. SPG7 often results in complicated forms of HSP with cerebellar involvement and/ or cerebellar atrophy, optic atrophy, ptosis, supranuclear palsy, ophthalmoplegia, cognitive impairment and dysexecutive syndrome $(8,10,11,12,13)$. Our patient had a complicated form of HSP without cognitive impairment. Although ptosis seen in HSP has been reported as bilateral symmetrical ptosis in the literature, it is rarely asymmetrical as in the case we presented (14). Also, SPG7 mutations are indicated as a rare cause of AD optic neuropathy and an important cause of sporadic progressive external ophthalmoplegia with multiple mitochondrial DNA mutations (6,15). In 2019, a review including 241 patients with SPG7 mutation was published. Results of the study states that spasticity-predominant phenotype is related with loss of function variants and that more frequent cerebellar ataxia and later onset is observed in patients carrying at least 1 Ala510Val variant. In this study, neurologic follow up was done only in 98 of these patients. Electromyography was performed only in 23 of the 241 patients and among these 23 patients 20 had sensorimotor axonal polyneuropathy, but in our case nerve conduction studies were normal (16). A recent study showed that SPG7 gene mutations can be responsible for $18.6 \%$ of patients with undiagnosed ataxia presenting in mid-adult life. Ataxia was the predominant feature in these patients and all of them did not have pyramidal signs initially, but during long-term follow-up pyramidal signs were found on repeat examinations $(17,18)$.

Exome sequencing analysis provides a high yield approach for the molecular diagnosis of undiagnosed ataxia. Sun et al. (19) identified pathogenic and suspected diagnostic variants in 88 patients of 170 patients with undiagnosed ataxia with a positive diagnostic rate of $52 \%$. Among mutation positive patients, SPG7 gene mutation rate was $9 \%$ (19). Recent studies which were carried out among different populations showed that SPG 7 mutation was a frequent cause in undiagnosed cerebellar ataxias (17). Thus, SPG 7 should be considered in undiagnosed cerebellar ataxias after ruling out the most common etiologies.

We reported a rare cause of ataxia in a Turkish patient with HSP SPG 7 with clinical features, MRI findings and genetic diagnosis which were achieved by whole exam sequencing in compatible with recent literature.

\section{Ethics}

Informed Consent: Written consent was obtained.

Peer-review: Externally peer-reviewed.

\section{Authorship Contributions}

Surgical and Medical Practices: A.Ç., B.Ö.B., R.A.İ., Concept: A.Ç., B.Ö.B., Design: B.Ö.B., Data Collection or Processing: A.Ç., Analysis or Interpretation: A.Ç., B.Ö.B., Literature Search: A.Ç., B.Ö.B., Writing: A.Ç.

Conflict of Interest: No conflict of interest was declared by the authors.

Financial Disclosure: The authors declared that this study received no financial support.

\section{References}

1. Harding AE. Hereditary spastic paraplegias. Semin Neurol 1993;13:333-336

2. Salinas S, Proukakis C, Crosby A, Warner TT. Hereditary spastic paraplegia: clinical features and pathogenetic mechanisms. Lancet Neurol 2008;7:11271138 .

3. Fink JK. Advances in the hereditary spastic paraplegias. Exp Neurol 2003;184(Suppl 1):S106-S110.

4. Finsterer J, Löscher W, Quasthoff S, et al. Hereditary spastic paraplegias with autosomal dominant, recessive, X-linked, or maternal trait of inheritance. J Neurol Sci 2012;318:1-18.

5. Ruano L, Melo C, Silva MC, Coutinho P. The global epidemiology of hereditary ataxia and spastic paraplegia: a systematic review of prevalence studies. Neuroepidemiology 2014;42:174-183.

6. Klebe S, Depienne C, Gerber S, et al. Spastic paraplegia gene 7 in patients with spasticity and/or optic neuropathy. Brain 2012;135:2980-2993.

7. De Michele G, De Fusco M, Cavalcanti F, et al. A new locus for autosomal recessive hereditary spastic paraplegia maps to chromosome 16q24.3. Am J Hum Genet 1998;63:135-139.

8. Casari G, De Fusco M, Ciarmatori S, et al. Spastic paraplegia and OXPHOS impairment caused by mutations in paraplegin, a nuclear-encoded mitochondrial metalloprotease. Cell 1998;93:973-983.

9. Nolden M, Ehses S, Koppen M, et al. The m-AAA protease defective in hereditary spastic paraplegia controls ribosome assembly in mitochondria. Cell 2005;123:277-289.

10. Warnecke T, Duning T, Schwan A, et al. A novel form of autosomal recessive hereditary spastic paraplegia caused by a new SPG7 mutation. Neurology 2007;69:368-375

11. Tzoulis C, Denora PS, Santorelli FM, Bindoff LA. Hereditary spastic paraplegia caused by the novel mutation 1047 insC in the SPG7 gene. J Neurol 2008;255:1142-1144.

12. Parodi L, Coarelli G, Stevanin G, Brice A, Durr A. Hereditary ataxias and paraparesias: clinical and genetic update. Curr Opin Neurol 2018;31:462-471.

13. Gass J, Blackburn PR, Jackson J, et al. Expanded phenotype in a patient with spastic paraplegia 7. Clin Case Rep 2017;5:1620-1622.

14. Bhattacharjee S, Beauchamp N, Murray BE, Lynch T. Case series of autosomal recessive hereditary spastic paraparesis with novel mutation in SPG 7 gene. Neurosciences (Riyadh) 2017;22:303-307.

15. Pfeffer G, Gorman GS, Griffin H, et al. Mutations in the SPG7 gene cause chronic progressive external ophthalmoplegia through disordered mitochondrial DNA maintenance. Brain 2014;137:1323-1336.

16. Coarelli G, Schule R, van de Warrenburg BPC, et al. Loss of paraplegin drives spasticity rather than ataxia in a cohort of 241 patients with SPG7. Neurology 2019;92:e2679-e2690.

17. Pfeffer G, Pyle A, Griffin H, et al. SPG7 mutations are a common cause of undiagnosed ataxia. Neurology 2015;84:1174-1176.

18. van de Warrenburg BP, Schouten MI, de Bot ST, et al. Clinical exome sequencing for cerebellar ataxia and spastic paraplegia uncovers novel genedisease associations and unanticipated rare disorders. Eur J Hum Genet 2017;25:393.

19. Sun M, Johnson AK, Nelakuditi V, et al. Targeted exome analysis identifies the genetic basis of disease in over $50 \%$ of patients with a wide range of ataxiarelated phenotypes. Genet Med 2019;21:195-206. 